1688 
The Lewis Walpole Series, published by Yale University Press with the aid of the Annie Burr Lewis Fund, is dedicated to the culture and history of the long eighteenth century (from the Glorious Revolution to the accession of Queen Victoria). It welcomes work in a variety of fields, including literature and history, the visual arts, political philosophy, music, legal history, and the history of science. In addition to original scholarly work, the series publishes new editions and translations of writing from the period, as well as reprints of major books that are currently unavailable. Though the majority of books in the series will probably concentrate on Great Britain and the Continent, the range of our geographical interests is as wide as Horace Walpole's. 


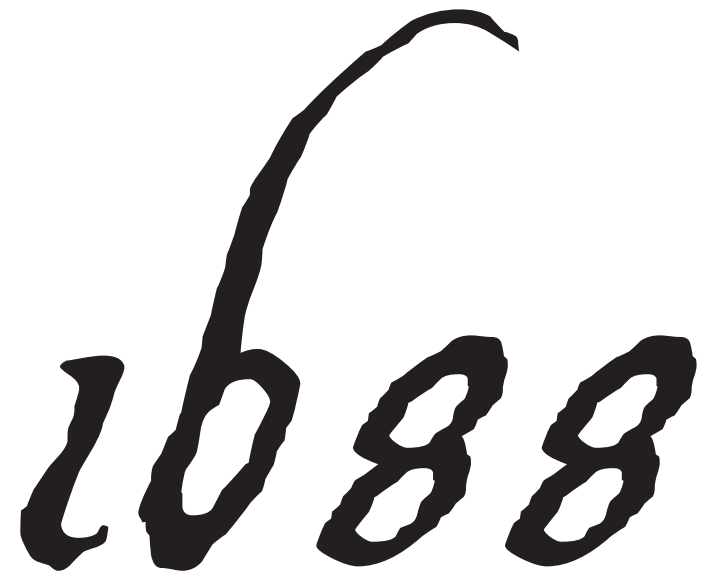

\section{THE FIRST MODERN REVOLUTION} STEVE PINCUS 
Published with the assistance of the Frederick W. Hilles Publication Fund of Yale University; the Kingsley Trust Association Publication Fund established by the Scroll and Key Society of Yale College; and the Annie Burr Lewis Fund.

\section{Copyright (C) 2009 by Yale University.}

All rights reserved.

This book may not be reproduced, in whole or in part, including illustrations, in any form (beyond that copying permitted by Sections 107 and 108 of the U.S. Copyright Law and except

by reviewers for the public press), without written permission from the publishers.

Designed by James J. Johnson and set in Adobe Garamond type by Duke \& Company, Devon, Pennsylvania.

Printed in the United States of America.

\section{Library of Congress Cataloging-in-Publication Data \\ Pincus, Steven C. A. \\ I688 : the first modern revolution / Steve Pincus.}

p. $\quad$ cm. - (The Lewis Walpole series in eighteenth-century culture and history)

Includes bibliographical references and index.

$$
\text { ISBN 978-0-300-II547-5 }
$$

I. Great Britain-History-Revolution of I688. 2. Great Britain-History-Revolution of I688-

Historiography. 3. Great Britain-History-Revolution of I688-Social aspects. I. Title.

$$
\begin{gathered}
\text { DA452.P53 } 2009 \\
941.06^{\prime} 7-\mathrm{dc} 22 \\
2009004607
\end{gathered}
$$

A catalogue record for this book is available from the British Library.

This paper meets the requirements of ANSI/NISO Z39.48-1992 (Permanence of Paper). 